\title{
Systemic Sarcoidosis Induced by Chemotherapy, Mimicking Metastatic Testicular Carcinoma with ${ }^{18} \mathrm{~F}-\mathrm{FDG}$ PET/CT
}

\author{
${ }^{18}$ F-FDG PET/BT Görüntülemede Metastatik Testis Karsinomunu Taklit Eden Kemoterapi \\ Tedavisinin Indüklediği Sistemik Sarkoidoz
}

\author{
(1) Esra Arslan', (1) Tamer Aksoy', (1) Süheyla Ekemen², (1) Tevfik Fikret Çermik1 \\ IUniversity of Health Sciences Turkey, Istanbul Training and Research Hospital, Clinic of Nuclear Medicine, Istanbul, Turkey \\ 2Bahçeşehir University Faculty of Medicine, Department of Pathology, Istanbul, Turkey
}

\begin{abstract}
A 34-year-old male patient who had left orchiectomy and received three cycles of chemotherapy for testicular mix germ cell carcinoma was referred for ${ }^{18}$ fluorine-fluorodeoxyglucose $\left({ }^{18} \mathrm{~F}-\mathrm{FDG}\right)$ positron emission tomography/computed tomography (PET/CT) for complaints of weight loss and fever. PET/CT showed multiple and progressive ${ }^{18} \mathrm{~F}-\mathrm{FDG}$ uptakes in supra and infra diaphragmatic lymphatic regions, and multiple abnormal ${ }^{18} \mathrm{~F}$-FDG uptakes were noted in the lytic formed skeletal lesions. Clinicians remain in doubt regarding the multiple metastatic lesions without elevated serum tumor marker levels (alpha-fetoprotein, beta-human chorionic gonadotrophin, CA19-9, and carcinoembryonic antigen).

Biopsy of the lytic lesion in the iliac bone revealed granulomatous inflammation suggestive of sarcoidosis. Systemic prednisone at 20-40 mg/daily was started. ${ }^{18} \mathrm{~F}-\mathrm{FDG}$ PET/CT images showed complete metabolic response to prednisone 8 months following the start of treatment.

Keywords: Systemic sarcoidosis, testis carcinoma, ${ }^{18} \mathrm{~F}-\mathrm{FDG}$ PET/CT
\end{abstract}

\section{Öz}

Orşiektomi yapılan ve testis mikst germ hücreli karsinomu tanısı nedeni ile 3 kür kemoterapi alan 34 yaşındaki erkek hastada, kilo kaybı şikayeti nedeniyle nüks hastalık şüphesi ile ${ }^{18 f l o r-f l o r o d e o k s i g l u k o z ~(18 F-F D G) ~ p o z i t r o n ~ e m i s y o n ~ t o m o g r a f i / b i l g i s a y a r l ı ~ t o m o g r a f i ~(P E T / B T) ~ g o ̈ r u ̈ n t u ̈ l e m e s i ~}$ yapıldı. PET/BT'de supra ve infra diyafragmatik lenfatik istasyonlarda çok sayıda ve patolojik FDG tutulumu gözlendi. Ayrıca litik görünümlü çok sayıda iskelet lezyonlarında da anormal ${ }^{18}$ F-FDG tutulumu kaydedildi. Klinisyen, serum tümör belirteç (alfa feto protein, beta insan koryonik gonadotropin, CA19-9 ve karsinoembriyonik antijen) düzeyi yükselmemiş metastatik multipl lezyonlar konusunda şüphelenerek olguya iliak kemikteki litik lezyondan biyopsi incelemesi önerdi. Histopatolojik sonuç sarkoidoz düşündüren granülomatöz inflamasyon gösteren odak olarak raporlanması üzerine günlük $20-40 \mathrm{mg} / \mathrm{gün}$ sistemik prednizon başlandı. Sistemik prednizon tedavisine başlandıktan 8 ay sonraki ${ }^{18} \mathrm{~F}-\mathrm{FDG}$ PET/BT görüntüleri tam metabolik yanıt göstermektedir.

Anahtar kelimeler: Sistemik sarkoidoz, testis karsinomu, ${ }^{18}$ F-FDG PET/BT

Address for Correspondence: Esra Arslan MD, University of Health Sciences Turkey, İstanbul Training and Research Hospital, Clinic of Nuclear Medicine, İstanbul, Turkey

Phone: +90 2124596455 E-mail: dresraarslan@gmail.com ORCID ID: orcid.org/0000-0002-9222-8883

Received: 10.11.2019 Accepted: 13.06.2020

${ }^{\circ}$ Copyright 2021 by Turkish Society of Nuclear Medicine

Molecular Imaging and Radionuclide Therapy published by Galenos Yayınevi. 

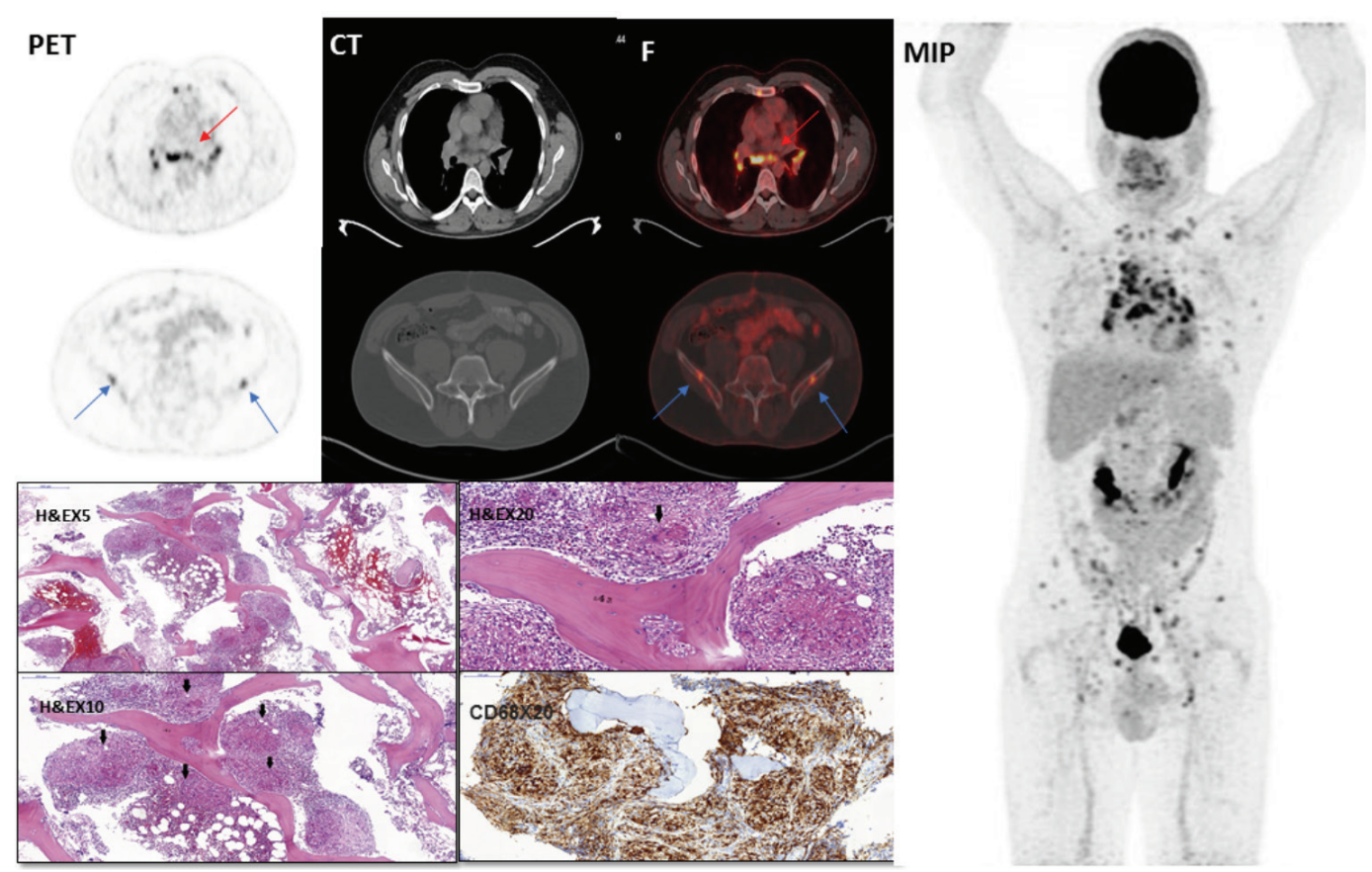

Figure 1. A 34-year-old male patient presented with fever, fatigue, and weight loss 4 months after left orchiectomy and three cycles of bleomycin, etoposide, and platinum chemotherapy due to testicular mix germ cell carcinoma (60\% embryonal carcinoma, 30\% teratoma, $10 \%$ yolk sac tumor), pT1NxMx. Although the patient had no laboratory abnormalities (serum alpha-fetoprotein, beta-human chorionic gonadotrophin, CA199 , and carcinoembryonic antigen levels were in normal ranges), ${ }^{18}$ fluorine-fluorodeoxyglucose ( $\left.{ }^{18} \mathrm{~F}-\mathrm{FDG}\right)$ positron emission tomography/computed tomography (PET/CT) was performed to evaluate metastatic disease as the patient suffered from excessive weight loss, fatigue, and fever. Written and verbal informed consents were obtained from the patient. Axial PET images and PET/CT fusion images show hypermetabolic mediastinal lymph nodes (red arrows), and abnormal focal ${ }^{18}$ F-FDG uptakes were noted on the bilateral iliac bones (blue arrows). Multiple hypermetabolic supra and infra diaphragmatic lymph nodes and multiple bone lesions with increased ${ }^{18} \mathrm{~F}-\mathrm{FDG}$ uptakes were noted on maximum intensity projection images of PET examination. Biopsy of the lytic lesion in the iliac bone suggested granulomatous inflammation, instead of malignant cells. In H\&EX5 staining, granuloma structures between bone trabeculae were seen. In H\&EX10 image, black arrows show non-caseating granulomas. In H\&EX20 image, black arrow shows multinuclear giant cells in the central of the granuloma. In CD68X20 staining, immunohistochemically positivity of histiocytes with CD68 was noted.

Sarcoidosis is a systemic granulomatous disease presenting with non-caseating epithelioid granuloma that primarily affects the lung and lymphatic systems of the body (1). The relationship between granulomatosis and cancer have been reported $(2,3,4)$. Moreover, several reports have described the association between sarcoidosis and antineoplastic treatment $(5,6,7,8)$. Another theory proposed that testicular cancers may be accompanied by a sarcoid-like reaction or can be associated with real sarcoidosis (8). 

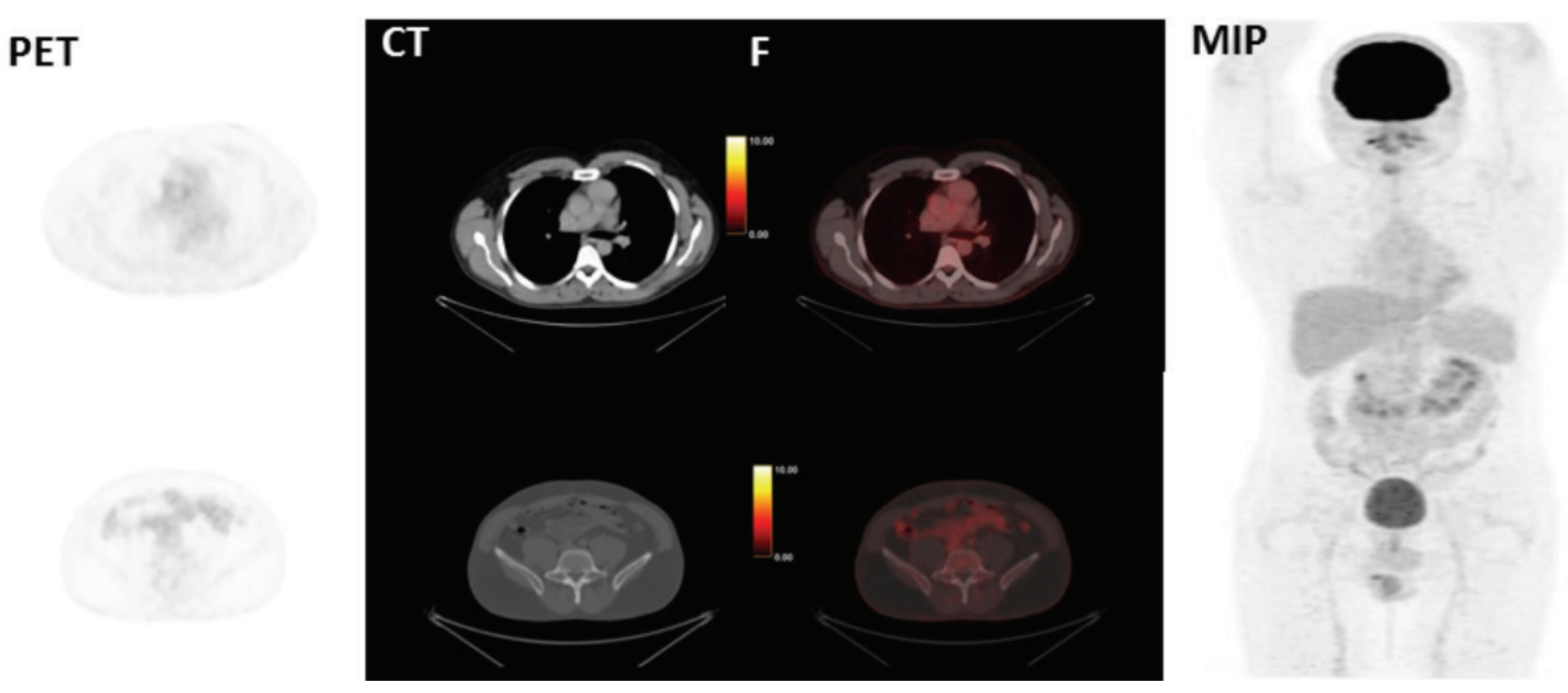

Figure 2. ${ }^{18} \mathrm{~F}-\mathrm{FDG} \mathrm{PET} / \mathrm{CT}$ images demonstrate complete metabolic response to systemic $20-40 \mathrm{mg} /$ daily prednisone treatment after 8 months.

\section{Ethics}

Informed Consent: Was obtained from the patient.

Peer-review: Externally peer-reviewed.

\section{Authorship Contributions}

Surgical and Medical Practices: S.E., Concept: E.A., T.A., S.E., T.F.Ç., Design: E.A., T.A., S.E., T.F.Ç., Data Collection or Processing: E.A., T.A., S.E., T.F.Ç., Analysis or Interpretation: E.A., T.A., S.E., T.F.Ç., Literature Search: E.A., T.A., S.E., T.F.Ç., Writing: E.A., T.A., T.F.Ç.

Conflict of Interest: No conflict of interest was declared by the authors.

Financial Disclosure: The authors declared that this study received no financial support.

\section{References}

1. Statement on sarcoidosis. Joint Statement of the American Thoracic Society (ATS), the European Respiratory Society (ERS) and the World Association of Sarcoidosis and Other Granulomatous Disorders (WASOG) adopted by the ATS Board of Directors and by the ERS Executive Committee, February 1999. Am J Respir Crit Care Med 1999;160:736755 .
2. Rømer FK, Hommelgaard P, Schou G. Sarcoidosis and cancer revisited: a long-term follow-up study of 555 Danish sarcoidosis patients. Eur Respir J 1998;12:906-912.

3. Pavic M, Debourdeau P, Vacelet V, Rousset $H$. Place de la pathologie granulomateuse au cours des cancers [Sarcoidosis and sarcoid reactions in cancer]. Rev Med Interne 2008;29:39-45.

4. Grados A, Ebbo M, Bernit E, Veit V, Mazodier K, Jean R, Coso D, AurranSchleinitz T, Broussais F, Bouabdallah R, Gravis G, Goncalves A, Giovaninni $M$, Sève $P$, Chetaille B, Gavet-Bongo F, Weitten $T$, Pavic M, Harlé JR, Schleinitz N. Sarcoidosis Occurring After Solid Cancer: A Nonfortuitous Association: Report of 12 Cases and Review of the Literature. Medicine (Baltimore) 2015;94:e928.

5. Wirk B. Sarcoid Reactions after Chemotherapy for Hodgkin's Lymphoma. Clin Med Insights Case Rep 2010;3:21-25.

6. Inoue $K$, Goto R, Shimomura H, Fukuda H. FDG-PET/CT of sarcoidosis and sarcoid reactions following antineoplastic treatment. Springerplus 2013;2(1):113

7. Sanan P, Lu Y. Multiorgan Involvement of Chemotherapy-Induced Sarcoidosis Mimicking Progression of Lymphoma on FDG PET/CT. Clin Nucl Med 2017;42:702-703

8. Paparel $P$, Devonec $M$, Perrin $P$, Ruffion $A$, Decaussin-Petrucci $M$, Akin $\mathrm{O}$, Sheinfeld J, Guillonneau B. Association between sarcoidosis and testicular carcinoma: a diagnostic pitfall. Sarcoidosis Vasc Diffuse Lung Dis 2007;24:95-101. 